\title{
Index of Student Satisfaction with Service at the Faculty of Economics, Batanghari Jambi University
}

\author{
M. Alhudhori, Amalia Paramita Sari \\ Fakultas Ekonomi Universitas Batanghari \\ Correspondence email: alhudhori811@gmail.com
}

\begin{abstract}
This research aims to find out the academic service to students at the Faculty of Economics, Batanghari Jambi University and to find out student satisfaction with Academic service at the Faculty of Economics, Batanghari Jambi University. The variable in this research is one, namely student satisfaction with academic service. The sample in this study was all students of the Faculty of Economics unbari numbered 81 people. The instruments used in this study are documentation to obtain forms of academic service and questionnaires to obtain student satisfaction scores for academic service. Data analysis techniques used are quantitative descriptive analysis techniques using percentage formulas to answer the second problem formulation. Through the method and analysis of the data showed that the level of student satisfaction with academic service at the Faculty of Economics, Batanghari Jambi University, was a student who was in the high category was 6 people with a percentage of 7.4\%, and those in the moderate category were 58 people with a percentage of $71.6 \%$, while the lowest chose were 17 people with a percentage of 20.9\%. Thus the level of student satisfaction with academic services at the Faculty of Economics, Batanghari Jambi University is in the moderate category of 58 students with a percentage of $71.6 \%$.
\end{abstract}

Keywords : index, satisfaction, service

\section{Introduction}

As one of the important components in the implementation of universities, the student satisfaction index (IKM) is one of the important indicators in the assessment of the quality of college implementation. Student satisfaction in his position as a student, can be divided into several aspects, including: satisfaction in following the teaching and learning process, satisfaction in receiving services (academic administration and student affairs), as well as satisfaction in using the facilities and infrastructure provided by the college. Student satisfaction in following the teaching and learning process can be reflected through: the availability of curriculum and learning process, lecturers who are quality and qualifications of lecturers, lecture atmosphere, lecture materials and lecturers' ability to deliver lecture materials, as well as knowledge and skills obtained after attending lectures. To improve the quality of the teaching and learning process at the Faculty of Economics, Batanghari Jambi University is considered necessary to explore the level of student satisfaction in teaching and learning activities, so that it can be used as input for improving the quality of the teaching and learning process as well as for the preparation of academic policies for the Faculty. (Suryani, 2011).

In addition to being students who are entitled to the services of the teaching and learning process, students in their activities on campus are also entitled to administrative services as part of the academic and student system (Kotler, 2002). Administrative services are generally provided by the academic administration section. Good administrative services are an integral part of the quality of the implementation of the study program, and one of them is reflected by the satisfaction for service recipients. In this regard, there is a need for feedback from students as service users, in order to improve the quality of service and in the framework of the preparation of policies related to administrative services. Faculty of Economics, Batanghari Jambi University, one of the faculties at Batanghari Jambi University which is one of the largest private universities in Jambi Province as an educational institution must be committed to continuing to build the academic atmosphere and service aspects in the Faculty. One indicator of professional university management is if the institution is able to provide public services to qualified students. One of them is academic services related to the continuity of lectures and direct contact with students. Students have a role as assessors of the quality of service. (Gaspersz, 2002)

According to Berry and Parasuraman (1985) there are five indicators of student satisfaction in relation to academic services, namely: (1) Reliability, related to employee service in providing quality service with promised, consistent, always in place, in accordance with the needs and expectations of students; (2) Responsiveness, service and resolution of student complaints is done with responsiveness, speed, and appropriate and the willingness of academic personnel to listen and overcome student complaints related to lecture problems such as the management of study plan cards (SPC), Grades, etc., which concerns lecture problems; (3) Certainty, which is a situation in which the academic provides assurance of service certainty to students who are not separated from the ability or expertise of academic personnel, especially leaders, employees or staff to generate confidence and confidence in academic promises to students, in addition to other services. Such as: placement of staff or personnel in accordance with the position carried 
out, thorough on the work, etc; (3) Empathy, is a mental state that makes a person feel himself in the state of others. Thus the form of empathy for the needs of students is to understand, understand and feel what the student needs, quickly respond to student complaints, ease and clarity in providing services in accordance with the needs of each student, attitude shown to students such as (friendly, polite, appreciative, cheap smile) and strive towards achievement; and (6) Tangible, which deals with the physical aspects necessary to support the teaching and learning process, including; buildings, lecture facilities such as chair tables etc., environmental cleanliness, laboratories, libraries, toilets and others (Lupriyoadi, 2008)

The academic service process of the Faculty of Economics Unbari related to student satisfaction is a study in this study, where the expectation in the academic service process there are still many problems that writers get in the field, there are several complaints that researchers see such as: (1) Less quickly provide services because the employee concerned took too long to check and correct the student files word-for-word even though there are still many other students who queue; Not responding to student problems or complaints that arise such as management and improvement of absences if something goes wrong, study plan card (KRS), grades and others; (3) Not exactly in accordance with the time or schedule that has been determined usually the employee concerned is late to arrive or postponed his schedule; (4) Showing a sour or grumpy face and indifference or dislike when serving students; (5) management of paraf and signatures that take up to a week or even more even though it can be completed within an hour because the employee concerned is busy or not in place; (6) less careful of the work so that there are still many errors such as file writing; (7) Less friendly; (8) Less smile; (9) Poor communication; (10) placement of employees who are not in accordance with the ability or discipline possessed so that the description of their duties is not well understood; (11) between students and each other; and (12) Academic activists who are still lacking so overwhelmed when serving so many students.

On the aspect of availability of facilities and infrastructure, it is routinely evaluated through feedback from students as users Feedback on the availability of facilities and infrastructure focused on aspects such as: (1) Comfort, cleanliness and safety of lecture halls, laboratory rooms, libraries, waiting rooms, student activity unit rooms, and public facilities; (2) Relevance, accuracy and timely SiAdin (academic information system); (3) Availability of hot spot bandwidth. Based on the background of the above problem, the formulation of the problem is: (1) what is the form of academic service to students at the Faculty of Economics Unbari Jambi, and (2) what is the satisfaction of students with Academic service at the Faculty of Economics Unbari Jambi.

\section{Method}

Student satisfaction survey activities are conducted on students from 3 (three) Study Programs, namely Prgram studies: Development Economics (S1), Management (S1) and Master of Management (S2). The time of the investigation took place in budget year 2021. For the effectiveness of survey activities, respondents in this activity are students of the Faculty of Economics, Batanghari Jambi University. The sampling method used is Saturation Sampling, where all members of the population (students of the Faculty of Economics, Batanghari Jambi University) are required to provide responses through questionnaires. (Sugiyono, 2004). The survey was conducted by providing questionnaires to respondents as data retrieval instruments. The method of filling out the questionnaire using online media (google form) where students before filling out the application form are required to fill out the questionnaire through their respective SiAdin accounts. The questionnaire consists of 25 question items divided into 3 aspects as follows: (1) Teaching and Learning Process; (2) Finance Department, General Academic Section and Student Affairs Section; and (3) Infrastructure Facilities. (Ramli, 2013); (Suhartini, 2012).

Table 1

The number of respondents

\begin{tabular}{|l|l|c|}
\hline No. & \multicolumn{1}{|c|}{ Courses } & Sum \\
\hline 1. & Master of Management & 179 \\
\hline 2. & Development Economics & 94 \\
\hline 3. & Management & 1.012 \\
\hline \multicolumn{2}{|c|}{ Total } & $\mathbf{1 . 2 8 5}$ \\
\hline
\end{tabular}

Source: Processed Data

\section{Results}


M. Alhudhori dan Amalia Paramita Sari, Index of Student Satisfaction with Service at the Faculty of Economics, Batanghari Jambi University

Table 2

Helper Table for Calculating Mean

\begin{tabular}{|l|r|r|r|}
\hline \multicolumn{1}{|c|}{ Interval } & \multicolumn{1}{|c|}{ Xi } & \multicolumn{1}{|c|}{ Fi.Xi } \\
\hline $50-53$ & 2 & 51,5 & 103 \\
\hline $54-57$ & 11 & 55,5 & 610,5 \\
\hline $58-61$ & 24 & 59,5 & 1428 \\
\hline $62-65$ & 30 & 63,5 & 1905 \\
\hline $66-69$ & 10 & 67,5 & 675 \\
\hline $70-73$ & 2 & 71,5 & 143 \\
\hline $74-77$ & 1 & 75,5 & 75,5 \\
\hline $78-81$ & 1 & 79,5 & 79,5 \\
\hline Jumlah & $\mathbf{8 1}$ & & $\mathbf{5 0 1 9 , 5}$ \\
\hline
\end{tabular}

Source: Processed Data

Table 2

Helper Table for Calculating Percentage Values

\begin{tabular}{|l|l|l|}
\hline Interval & Frekuensi & $\%$ \\
\hline $50-53$ & 2 & 2,5 \\
\hline $54-57$ & 11 & 13,6 \\
\hline $58-61$ & 24 & 29,7 \\
\hline $62-65$ & 30 & 37,0 \\
\hline $66-69$ & 10 & 12,3 \\
\hline $70-73$ & 2 & 2,4 \\
\hline $74-77$ & 1 & 1,2 \\
\hline $78-81$ & 1 & 1,2 \\
\hline Jumlah & & 101 \\
\hline
\end{tabular}

Source: Processed Data

The presentation of the above data that changes the frequency to percent $(\%)$, by paying attention to 81 students as a sample, 2 or $2.5 \%$ of students are in intervals (50-53), 11 or $13.6 \%$ of students are in intervals (54-57), 24 or $29.7 \%$ of students are in intervals (58-61), 30 or $37.0 \%$ of students are in intervals (62-65), 10 or $12.3 \%$ of students are in intervals (66-69), 2 or $2.4 \%$ of students are in intervals (70-73), 1 or $1.2 \%$ of students are in intervals (78-81), thus it can be concluded that the student satisfaction level score for academic services obtained from the results of the questionnaire, the lowest score of 50 and the highest score of 78, with the average level of percentage value of student satisfaction level towards academic services at the Faculty of Economics, Batanghari Jambi University (62-65) with a score of $37.0 \%$ obtained from 30: $81 \times 100 \%$.

Table 3

Deviation Standard Helper Table

\begin{tabular}{|c|c|c|c|c|c|c|}
\hline Interval & $\mathrm{Fi}$ & $\mathrm{Xi}$ & Fi.Xi & $\mathrm{Xi}^{-}$ & $(\mathrm{Xi}-\overline{-})$ & $\mathrm{Fi}\left(\mathrm{Xi}^{-} \overline{-}\right)$ \\
\hline $50-53$ & 2 & 51,5 & 103 & $-10,5$ & 110,25 & 220,5 \\
\hline $54-57$ & 11 & 55,5 & 610,5 & $-6,5$ & 42,25 & 464,75 \\
\hline 58-61 & 24 & 59,5 & 1428 & $-2,5$ & 6,25 & 150 \\
\hline $62-65$ & 30 & 63,5 & 1905 & 1,5 & 2,25 & 67,5 \\
\hline $66-69$ & 10 & 67,5 & 675 & 5,5 & 30,25 & 302,5 \\
\hline $70-73$ & 2 & 71,5 & 143 & 9,5 & 90,25 & 180,5 \\
\hline $74-77$ & 1 & 75,5 & 75,5 & 13,5 & 182,25 & 182,25 \\
\hline $78-81$ & 1 & 79,5 & 79,5 & 17,5 & 306,25 & 306,25 \\
\hline Jumlah & 81 & & 5019,5 & & & 1874,25 \\
\hline
\end{tabular}

Source: Processed Data

Based on the formula for calculating the standard deviation of data classified, the standard deviation is 4.84 . The results showed a large standard error in the score on the level of student satisfaction with academic service at the Faculty of Economics, Batanghari Jambi University. Because this study questionnaire amounted to 24 problem items with 4 alternative answers, and four assessment criteria, so that the score range of 50 to 78 was obtained from 81 students to respondents. Based on data on the level of student satisfaction with academic service at the Faculty of Economics, Batanghari Jambi University had the lowest score of 50 and the highest score of 78, with a mean of 62, with a standard deviation of 4.84 . The statistical count of description is collated to a scale of 3 . To make it easier to 
know the level of student satisfaction with academic services, details are made according to the value category. The details include three categories, namely; High categories, medium categories, and low categories, determined based on categorization theory by Saifuddin (2015). For more details can be seen in the following description:

Table 4

Category of Student Satisfaction Level Score for Academic Service

\begin{tabular}{|l|r|r|r|r|}
\hline \multicolumn{2}{|c|}{ Interval } & Frekuensi & Kategori & Persentase \\
\hline$X<57,52$ & $50-58$ & 17 & Rendah & $20,9 \%$ \\
\hline$X<66,84$ & $59-67$ & 58 & Sedang & $71,6 \%$ \\
\hline$X \geq 66,84$ & $68-76$ & 6 & Tinggi & $7,4 \%$ \\
\hline Jumlah & & 81 & & $100 \%$ \\
\hline
\end{tabular}

Source: Processed Data

Based on the table above provides an overview that the category of results in the level of student satisfaction with academic services is students who are in the high category is 6 people with a percentage of $7.4 \%$, and those in the moderate category are 58 people with a percentage of $71.6 \%$, while those who choose the lowest are 17 people with a percentage of $20.9 \%$. Thus the level of student satisfaction with academic services at the Faculty of Economics, Batanghari Jambi University is in the moderate category of 58 students with a percentage of $71.6 \%$.

The level of student satisfaction with academic services felt by students during the course until the semester to the Faculty of Economics after using or using existing services, students feel less satisfied with these services. The above statement is based on the calculation of research results in the field, results that explain from the dimensions of the standard measure of service or service in student satisfaction as he argued. Philip Kotler in the previous chapter, that the services presented according to the assessment of the results were less than standard. So that students feel less satisfied and even dissatisfied with existing academic services. That's because what they feel is not what they expect. Students' hopes for academic service are to get good service, fast, precise, meticulous, friendly, always ready to help, always in place and ready to serve students, professional and expert staff in their respective fields, neatness and cleanliness of the room, and completeness of facilities and pre-facilities and much more, all of which have not been realized properly by the Faculty of Economics, Batanghari Jambi University.

\section{Conclusion}

Based on the formulation of the problems that have been presented in the previous chapter and on the results of research that has been done, the conclusions that can be taken are as follows: (1) The form of academic service that has been owned by the faculty of Economists of Batanghari Jambi University is as follows: preparation of lecture schedules, academic leave, academic guidance, SPC management, mid-semester and end semester exams, practicum implementation, value improvement, thesis title submission, endorsement and determination of guidance lecturers, proposal seminars, research results seminars, comprehensive exams, practical work, implementation of Real work college, munaqasyah, degree management, value transik management, legalization of degrees, deeds and transik values, diploma replacement, graduation implementation; and (2) Student satisfaction with academic service at the Faculty of Economics, Batanghari Jambi University. Based on the processing of data that has been done from the results of the questionnaire about the level of student satisfaction with academic services is students who are in the high category is 6 people with a percentage of $7.4 \%$, and those in the moderate category are 58 people with a percentage of $71.6 \%$, while those who choose the lowest are 17 people with a percentage of $20.9 \%$. Thus the level of student satisfaction with academic services at the Faculty of Economics, Batanghari Jambi University is in the moderate category with a percentage of $71.6 \%$.

\section{References}

Azwar, Saifuddin. 2015, Penyusunan Skala Psikologi, Yogyakarta; Pustaka Pelajar

Gaspersz, Vincent. 2002, Manajemen Kualitas Dalam Industri Jasa. Jakarta: Gramedia Pustaka Utama

Kotler, Philip. 2002, Manajemen Pemasaran, Edisi Kedua belas. Jakarta: PT Indeks,

Lupriyoadi, Rambat. Manajemen Pemasaran Jasa, Edisi Dua. Jakarta: Salemba Empat, 2008.

Parasuraman, dkk. 1985, A Conceptual Model Service Quality and its Implication for Future Research. Journal of Marketing, Fall

Ramli, Muhammad. 2013, Manajemen Pelayanan Publik Berbasis Kemanusiaan. Makassar: Alauudin University Press Sugiyono. 2004, Metode Penelitian pendidikan. Bandung: Alfabeta

Suhartini, Eka. 2012, Kualitas Pelayanan Kaitannya dengan Kepuasan Konsumen. Makassar: Alauddin University Press

Suryani. 2011, Studi komparatif tingkat kepuasan mahasiwa terhadap penyelengaraan di institut pertanian bogor. Skripsi. Bogor: Fak. Ekonomi dan Manajemen institute pertanian bogor 
M. Alhudhori dan Amalia Paramita Sari, Index of Student Satisfaction with Service at the Faculty of Economics, Batanghari Jambi University 